\title{
Fitting lactation data with two mathematical models and extension factors for milk, fat and protein of Belgian dairy goats
}

\author{
A Zoa-Mboé 1, C Michaux 1, JC Detilleux 1, \\ FP Farnir ${ }^{1}$, C Kebers ${ }^{2}$, PL Leroy ${ }^{1}$ \\ 1 Department of Genetics, Faculty of Veterinary Medicine, University of Liège, \\ Sart Tilman, B 43, B-4000 Liège; \\ 2 Office de promotion des petits élevages en Wallonie, 4, rue des Champs-Élysées, \\ B-5590 Ciney, Belgium
}

(Received 3 March 1995; accepted 5 May 1996)

\begin{abstract}
Summary - Data for 18155 test day milk yields and fat and protein percentages recorded from 15 February 1988 to 1 September 1993 were obtained from the Office de promotion des petits élevages en Wallonie. Due to irregular test intervals and a variable number of tests per lactation, production was estimated at 25 day intervals $(25,50, \ldots, 250$ days). A total of 13773 test day records for AngioNubian, Chamoisee, Saanen and crossbreds were available for analysis. Parities were classified into 1 and $\geq 2$. The inverse polynomial and the incomplete gamma functions were fitted to test day milk yields in order to define the shape of the lactation curves for the various breeds and parities. Two data subsets were created by random selection of entire lactation data from the original data set, and both functions were fitted to test day milk yields within breed-parity classes. Parameters of equations estimated on a subset of the data were validated on the other subset. Estimates of peak yields were higher and times of peak yield later by the inverse polynomial method than by the incomplete gamma but remained within ranges found in the literature. Based on the coefficient of multiple determination $\left(R^{2}\right)$, both equations were equally accurate in fitting lactation data of a subset. Though average residual deviations were slightly higher with the inverse polynomial than with the incomplete gamma, the crossvalidation did not reveal any particular trend of residuals for any equation. For practical reasons, extension factors for milk, fat and protein yields were derived using the inverse polynomial and are presented.
\end{abstract}

dairy goats / inverse polynomial / incomplete gamma / extension factors

Résumé - Ajustement de deux modèles mathématiques aux productions journalières de lait et facteurs d'extrapolation pour le lait, la matière grasse et les protéines des chèvres laitières de Belgique. Cette étude a porté initialement sur 18155 contrôles élémentaires comportant chacun la production de lait et les taux de matière grasse et protéine, enregistrés entre le 15 février 1988 et le $1^{\text {er }}$ septembre 1993. Le nombre de contrôles et l'intervalle en jours entre contrôles successifs d'une 
même lactation étant très variables, les productions ont été estimées à intervalles réguliers de 25 jours $(25,50, \ldots, 250)$. Des lactations dont la production dans la zone du pic était inférieure à 1,5 kg/jour, qui comptaient moins de cinq contrôles en 200 jours, ou dont la production augmentait après le pic (supposé passé à 100 jours), ont été exclues des analyses. II en a résulté 13773 contrôles élémentaires appartenant aux races Anglo-Nubienne, Chamoisée, Saanen et Croisées. Deux équations de courbe de production laitière (la polynomiale inverse et la gamma incomplète) ont été ajustées aux productions journalières de lait à $25,50, \ldots, 250$ jours par race et parités (1 et $\geq 2)$ afin de déterminer les caractéristiques des courbes de lactation. Deux moitiés de fichier ont été constituées par répartition aléatoire des lactations et l'ajustement des mêmes équations a été réalisé sur les contrôles élémentaires intragroupe. Les courbes estimées sur une moitié de fichier ont été validées sur l'autre. Les estimations du pic de production et du moment des pics ont été plus élevées par la polynomiale inverse mais sont restées dans les limites trouvées dans la littérature. Sur la base des $\mathrm{R}^{2}$ obtenus, les deux modèles d'équations sont restés comparables sur les mêmes données. Les déviations moyennes ont été légèrement plus élevées (en valeur absolue) avec la polynomiale inverse. De manière générale, les deux modèles ont en moyenne surestimé les productions aux contrôles. Sur la validation croisée, les écarts résiduels moyens par les deux équations n'ont pas montré de tendance particulière, leurs déviations standard étant restées comparables pour un même fichier. Pour des raisons pratiques, les facteurs d'extrapolation ont été estimés à l'aide de la polynomiale inverse et sont présentés.

chèvre laitière / polynomiale inverse / gamma incomplète / facteur d'extrapolation

\section{INTRODUCTION}

Studies on the extension of partial or incomplete lactations of dairy goats are few (Ricordeau and Bouillon, 1967; Wiggans et al, 1979; Bouloc, 1991) compared to dairy cows, and in Belgium in particular, they are nonexistent. Meanwhile, there is a growing interest in dairy goat production in that country. If the Belgian dairy goat industry is to expand, researchers need to provide goat farmers with extension factors, genetic evaluations and other necessary and objective management tools.

In dairy goats, the duration of lactation is very variable. Extension of partial yields to total lactation yields at a standard length of lactation are needed for such management decisions as culling, mating and ranking of animals at different lactation stages (Ricordeau and Bouillon, 1967; Miller et al, 1972a; Keown and Van Vleck, 1973; Auran, 1976; Wiggans and Van Vleck, 1979; Wiggans et al, 1979), for the estimation of feeding needs and for the projection of dairyman's income. Increased precision in genetic evaluation of breeding stock was achieved by the addition of extended partial lactation to complete 305 day lactations (Van Vleck and Henderson, 1961; Christensen, 1970). The recent improvements of computer capabilities have rendered possible the use of test day milk yields to estimate breeding values without the need for extrapolation factors (Pander and Hill, 1993; Ptak and Schaeffer, 1993; Schaeffer and Sullivan, 1994).

Methods of predicting total yield from partial lactation or test day (TD) records include fitting curves, multiplicative factor ratio and regression methods. Various nonlinear functions fitted to lactation data have been reviewed (Masselin et al, 1987; Gipson and Grossman, 1990; Bouloc, 1991). They provide an estimation of daily milk yield as a function of time even if the biological interpretation of the parameters of some complex models is not easy. Multiplicative factors are ratios of total to cumulated partial lactations at a given lactation stage or TD. Simple regressions are based on the prediction of the remaining yield of the partial lactation with the last known TD yield and require 
knowledge of TD and remaining lactation means for the various test periods (Miller et al, 1972b; Wilmink, 1987). Multiple regression methods can represent either regressions on successive TD or on cumulative yields. Comparison of methods belonging to these three groups over the entire lactation, on the basis of accuracy, computer storage and ease of implementation, showed an important advantage for nonlinear models (Schaeffer et al, 1977).

Many studies on goat lactations have emphasized that the 305 day lactation period in use with dairy cows was not compatible with the average lactation period of goats (Ricordeau and Bouillon, 1967; Wiggans et al, 1979). Average lactation is about 230 days for primiparous goats and around 260 days for other parities (Bouloc, 1991; Boichard, personal communication). In fact, a standard lactation of 250 days has been adopted in France (Bouloc, 1991; Boichard et al, 1993).

Objectives of the present study were i) to derive parameter estimates of the lactation curves of dairy goats, ii) to compare two mathematical models in fitting the goat lactation data and iii) to develop extension factors for use in southern Belgium.

\section{MATERIALS AND METHODS}

A total of 18155 TD milk yield, and fat and protein percentages, recorded at various dates after kidding between 15 February 1988 and 1 September 1993, were provided by the Office de promotion des petits élevages en Wallonie (OPPEW), Ciney (Belgium). The number of TD per lactation and the interval in days between consecutive testings were very variable; therefore, a minimum of 4 TD was imposed on lactations over the first 200 days. Lactations with low daily milk yield $(<1.5 \mathrm{~kg})$ during the period from 15 to 80 days were discarded. Further elimination was for lactations with increasing yields after 100 days (it was assumed peak yield must have occurred within 100 days postpartum); if $T D_{i}$ is the first test beyond 100 days and $T D_{f}$ the last test, the entire lactation was dis- carded if the average of $T D_{i+1}$ to $T D_{f}$ was $>T D_{i}$. The final data set comprised 13773 TD records.

Four breeds were represented, namely AngloNubian, Chamoisee, Saanen and crossbreds, for parities 1 (primiparous) and $\geq 2$ (adults).

To avoid bias due to irregular test intervals in our data, TD milk, fat and protein yields were estimated at 25 day intervals $(25,50,75, \ldots, 250$ days) by linear interpolation or extrapolation. Based on a review of lactation curves in dairy goats (Gipson and Grossman, 1990) and reports on dairy cattle (Yadav et al, 1977; Batra, 1986), two mathematical models were selected and fitted to TD milk yields:

Model 1: $y_{t}=a t^{b} \theta-c t$ (incomplete gamma; Wood, 1967);

Model 2: $y_{t}=t /\left(a+b t+c t^{2}\right)$ (inverse polynomial; Nelder, 1966)

where $y_{t}$ is TD milk yield at time $t$; $t$ is time of test calculated as date of test minus date of kidding; $e$ is the base of natural logarithms and $a, b, c$ are parameters to be estimated for each model. For both equations, $y_{t}=0$ for $t=0$.

Peak yield and time of peak yield for the eight breed-parity classes were derived. For the incomplete gamma ( $\mid \mathrm{G})$, the time of peak yield is given by $b / c$ and peak yield by $a(b / c)^{b} e^{-b}$; for the inverse polynomial (IP), they are given by $(a / c)^{1 / 2}$ and $\left(b+2(a c)^{1 / 2}\right)^{-1}$, respectively.

A large percentage of goats naturally go dry before 250 days; for the extension of completed records less than 250 days to be unbiased, a restriction on total days in milk was not imposed.

For the cross-validation, two data subsets (data set 1 and data set 2) were created from the original data by random selection of the entire lactation records. The parameters were estimated from each data subset using IP and IG and validated on the other, to determine the most suitable model. The models were fitted to individual TD yields within each breed-parity class and parameters were estimated by nonlinear regression using the NLIN procedure and the Marquardt iteration method, with convergence criteria of $10^{-8}$ (SAS, 1985). The criterion used for comparing the fit of the models to individual TD yields was the coefficient of multiple determination $\left(R^{2}\right)$ and the criteria used for evaluating the cross-validation were the $R^{2}$, the average of residual deviations (observed minus predicted values), and their standard deviations. 
The parameters obtained from the model that best fitted the data were to be used to derive extension factors based on partial lactation, or on partial lactation and last TD yields. Partial lactation is used for a complete lactation $<250$ days while partial lactation and last TD are used for an incomplete lactation. Based on partial yield $\left(Y_{p}\right)$, total yield $\left(Y_{e}\right)$ was estimated as $Y_{\theta}=k Y_{p}$, $k$ being the extrapolation factor; with last TD $\left(y_{t}\right)$ available, $Y_{\theta}=Y_{p}+c(250-t) y_{t}, c$ being the extrapolation factor and $t$, the length of partial yield in days.

\section{RESULTS AND DISCUSSION}

\section{Parameters of the lactation curves}

The $R^{2}$ resulting from fitting IG and IP to individual TD yields of the whole data set and of the subsets are in tables I and II, respectively. The IP and IG functions equally fitted the lactation data of goats in the present study. The $R^{2}$ were slightly higher for data set 2 than for data set 1 , except for the Chamoisee, parity $=1$.

Peak yields (PY) and time of peak yield (TPY) as estimated with IP and IG for the eight breed-parity classes are shown in table I. The estimates of PY for both models were relatively close, and falling within the range found in the literature ( 3 and $6 \mathrm{~kg} / \mathrm{day}$; Gipson and Grossman, 1990). The PY for the adult goats (parities $\geq 2$ ) were higher than for primiparous. This is in accordance with observations in other dairy goat studies (Gipson and Grossman, 1990). Highest PY occurred with the Saanen and the Chamoisee breeds ( 3.86 and $3.84 \mathrm{~kg}$ by IG, 3.95 and $3.88 \mathrm{~kg}$ by IP, respectively).

Time of peak yield occurred later with the IG function except for the Saanen and crossbreds, parities $\geq 2$. The highest difference between the TPY obtained from both functions (17 days) occurred with adult Chamoisee. In a review by Gipson and Grossman (1990), TPY occurred between

Table I. Characteristic estimates of parameters of lactation curves by breed and parity, whole data set.

\begin{tabular}{|c|c|c|c|c|c|c|c|}
\hline \multirow[t]{2}{*}{ Breed } & \multirow[t]{2}{*}{ Parity } & \multicolumn{3}{|c|}{ Incomplete gamma } & \multicolumn{3}{|c|}{ Inverse polynomial } \\
\hline & & $\begin{array}{l}\mathrm{R}^{2} \\
(\%)\end{array}$ & $\begin{array}{c}\text { Time of peak } \\
\text { yield } \\
\text { (days) }\end{array}$ & $\begin{array}{c}\text { Peak } \\
\text { yield } 2 \\
(\mathrm{~kg} / \text { day })\end{array}$ & $\begin{array}{l}R^{2} \\
(\%)\end{array}$ & $\begin{array}{c}\text { Time of peak } \\
\text { yield }{ }^{3} \\
\text { (days) }\end{array}$ & $\begin{array}{c}\text { Peak } \\
\text { yield4 } \\
(\mathrm{kg} / d a y)\end{array}$ \\
\hline \multirow[t]{2}{*}{ Anglo-Nubian } & 1 & 91.3 & 49 & 3.00 & 91.2 & 39 & 3.00 \\
\hline & $\geq 2$ & 89.8 & 43 & 3.32 & 89.4 & 30 & 3.32 \\
\hline \multirow[t]{2}{*}{ Chamoisee } & 1 & 89.8 & 46 & 2.82 & 89.5 & 30 & 2.80 \\
\hline & $\geq 2$ & 87.2 & 49 & 3.84 & 86.4 & 32 & 3.76 \\
\hline \multirow[t]{2}{*}{ Saanen } & 1 & 84.9 & 58 & 2.99 & 84.9 & 50 & 3.02 \\
\hline & $\geq 2$ & 82.9 & 31 & 3.86 & 82.8 & 40 & 3.95 \\
\hline \multirow[t]{2}{*}{ Crossbreds } & 1 & 90.9 & 58 & 3.13 & 90.7 & 49 & 3.12 \\
\hline & $\geq 2$ & 90.3 & 32 & 3.80 & 90.2 & 42 & 3.88 \\
\hline
\end{tabular}

Computed as: ${ }^{1} b / c,{ }^{2} a(b / c)^{b} e^{-b},{ }^{3}(a / c)^{1 / 2},{ }^{4}\left(b+2(a c)^{1 / 2}\right)^{-1}$ where $a, b, c$ are the parameters of the incomplete gamma and the inverse polynomial functions, and $e$ the base of natural logarithms. 
Table II. Coefficient of multiple determination $\left(R^{2}\right)$ from fitting lactation curves to test day milk yields on data sets 1 and 2 .

\begin{tabular}{|c|c|c|c|c|c|}
\hline \multirow[t]{3}{*}{ Breed } & \multirow[t]{3}{*}{ Parity } & \multicolumn{4}{|c|}{$\mathrm{R}^{2}$} \\
\hline & & \multicolumn{2}{|c|}{ Incomplete gamma } & \multicolumn{2}{|c|}{ Inverse polynomial } \\
\hline & & Data set 1 & Data set 2 & Data set 1 & Data set 2 \\
\hline \multirow[t]{2}{*}{ Anglo-Nubian } & 1 & 90.4 & 92.2 & 90.4 & 92.1 \\
\hline & $\geq 2$ & 89.4 & 90.4 & 89.3 & 89.9 \\
\hline \multirow[t]{2}{*}{ Chamoisee } & 1 & 91.3 & 88.8 & 91.2 & 88.4 \\
\hline & $\geq 2$ & 86.5 & 88.0 & 86.2 & 87.2 \\
\hline \multirow[t]{2}{*}{ Saanen } & 1 & 82.9 & 87.3 & 82.9 & 87.2 \\
\hline & $\geq 2$ & 80.0 & 85.9 & 79.9 & 85.9 \\
\hline \multirow[t]{2}{*}{ Crossbreds } & 1 & 90.4 & 91.4 & 90.3 & 91.3 \\
\hline & $\geq 2$ & 88.5 & 91.4 & 88.5 & 91.8 \\
\hline
\end{tabular}

15 and 80 days. Gipson and Grossman (1987) obtained estimates of TPY pooled for Alpine, LaMancha, Nubian, Saanen and Toggenburg for first parity at 53 days and for parities $\geq 2$ at 46 days with the IG. Estimates of TPY in our study were higher for primiparous than for adults, except for the Chamoisee. Estimates of parameters for IG and IP were given by Mukundan and Bhat (1983) for the Malabari and Saanen halfbreds from which we computed TPY and PY; IG gave lower TPY and higher PY than IP. Gipson and Grossman (1987) observed that TPY was generally later in first lactations than in later parites. Before the latest TPY in this study (58 days), there were only 2 TD (at 25 and 50 days). Therefore, more testings are required around TPY for more precise estimations of PY and TPY. Infrequent or unequally spaced sampling lead to biases in estimating characteristic parameters of the lactation curve (Anderson et al, 1989).

The $R^{2}$ resulting from fitting IG and IP to individual TD yields of both data subsets are shown in table II. The IP and IG functions equally fitted the TD milk yields of a given subset. Yadav et al (1977) compared four models for fitting lactation curves (expo- nential, parabolic exponential, gamma and inverse polynomial) on the average weekly milk yields for Hariana and its Friesian crosses and reported that an IP function provided the best fit, followed by the gamma function, ( $R^{2}=99$ and $95 \%$, respectively). Batra (1986) also obtained higher $R^{2}$ values with IP compared to a modified gamma function proposed by Kuck et al (1976). In these studies, the equations were linearized and parameters estimated by multiple linear regression on average daily milk yield in a week. Mukundan and Bhat (1983) also reported the IP function explained a higher percentage of the variation than did the IG function. Several other factors than those considered in this study, such as level of production and season of kidding, have been cited as factors affecting the lactation curve in dairy goats (Gipson and Grossman, 1990). However, because of the small number of records in some breed-parity groups, they were not considered here.

In most studies comparing the $R^{2}$ of the IP and IG, the equations were transformed to linear forms for parameter estimation. It has been pointed out that, when functions for different transformations of the data are used, the $R^{2}$ was not a valid criterion for 
comparing functions (Grossman and Koops, 1988; Gipson and Grossman, 1990). The log-linear form of IG introduces a bias in the estimation of parameters because $(t)$ and $\log (t)$ are not independent, the residuals are not randomly distributed, and a better fit is obtained with nonlinear regression (Masselin et al, 1987). Parameters in our study were estimated with nonlinear regression; on the whole data set, they also have been estimated by linear regression and the IP showed a slightly better fit (results not shown).

\section{Cross-validation of the models}

The $R^{2}$ resulting from fitting IP and IG to TD yields of the whole data set were close to those obtained with both subsets. Table III shows the average TD milk yields and the standard deviations at $25,50, \ldots, 250$ days for the whole data set and the two subsets selected at random. Based on average TD and standard deviations at $25, \ldots$, 250 days, all three data sets were comparable; the largest differences between mean TD milk yields were found at 25 and 50 days. The TD milk yields were also more variable at early than at mid- or late lactation. Average residual deviations and their standard deviations, and coefficients of variation of cross- validating IG and IP on data set 1 and data set 2 are shown in tables IV and $V$, respectively. Parameters estimated from data set 1 with each equation were applied to individual TD in data set 2 and vice versa (cross-validation). The purpose of this crossvalidation was to compare the methods rather than the parameters. Standard deviations of residuals were similar for a given data set whatever the model applied. Overestimation (negative residual deviations) and underestimation (positive residual deviations) of TD milk yields by a model for the same breed-parity class were maintained for each data set by the other model. Except for parities $\geq 2$ of the Chamoisee breed (on data set 1), average residual deviations were very similar for a given data subset, whatever the model. Average deviations from observed TD milk yields were $\leq 0.20 \mathrm{~kg}$ for IG on both data sets; for IP, except for the highest value at $0.24 \mathrm{~kg}$, they remained below $0.20 \mathrm{~kg}$. Based on the data of this study, evidence of the most suitable model

Table III. The numbers of observations, means and standard deviations (SD) of test day milk yields at 25 day intervals for the whole data set and the two subsets.

\begin{tabular}{|c|c|c|c|c|c|c|c|c|c|}
\hline \multirow{2}{*}{$\begin{array}{l}\text { Lactation } \\
\text { period } \\
\text { (days) }\end{array}$} & \multicolumn{3}{|c|}{ Whole data set } & \multicolumn{3}{|c|}{ Data set 1} & \multicolumn{3}{|c|}{ Data set 2} \\
\hline & $n$ & Mean $(\mathrm{kg})$ & $S D$ & $n$ & Mean $(\mathrm{kg})$ & $S D$ & $n$ & Mean $(k g)$ & $S D$ \\
\hline 25 & 2056 & 3.44 & 1.64 & 1009 & 3.52 & 1.73 & 1047 & 3.36 & 1.55 \\
\hline 50 & 2066 & 3.41 & 1.39 & 1014 & 3.48 & 1.46 & 1052 & 3.34 & 1.30 \\
\hline 75 & 2069 & 3.32 & 1.25 & 1017 & 3.35 & 1.32 & 1052 & 3.29 & 1.17 \\
\hline 100 & 2069 & 3.19 & 1.18 & 1017 & 3.19 & 1.22 & 1052 & 3.18 & 1.14 \\
\hline 125 & 2039 & 3.02 & 1.12 & 1002 & 3.00 & 1.15 & 1037 & 3.03 & 1.10 \\
\hline 150 & 1959 & 2.77 & 1.08 & 955 & 2.76 & 1.11 & 1004 & 2.78 & 1.05 \\
\hline 175 & 1850 & 2.55 & 1.06 & 905 & 2.53 & 1.08 & 945 & 2.57 & 1.05 \\
\hline 200 & 1620 & 2.33 & 1.04 & 796 & 2.31 & 1.05 & 824 & 2.34 & 1.03 \\
\hline 225 & 1375 & 2.16 & 1.00 & 666 & 2.12 & 1.01 & 709 & 2.19 & 0.98 \\
\hline 250 & 914 & 1.99 & 0.89 & 439 & 1.96 & 0.90 & 475 & 2.00 & 0.87 \\
\hline
\end{tabular}


Table IV. Means, standard deviations (SD) and coefficients of variation (CV) of residual deviations (observed - predicted) when cross-validating the incomplete gamma and inverse polynomial function parameters estimated from data set 2 on data set 1 .

\begin{tabular}{|c|c|c|c|c|c|c|c|}
\hline \multirow[t]{2}{*}{ Breed } & \multirow[t]{2}{*}{ Parity } & \multicolumn{3}{|c|}{ Incomplete gamma } & \multicolumn{3}{|c|}{ Inverse polynomial } \\
\hline & & $\begin{array}{c}\text { Average } \\
\text { residual } \\
\text { deviation } \\
\quad(\mathrm{kg})\end{array}$ & $\begin{array}{c}S D \text { of } \\
\text { residual } \\
\text { deviation }\end{array}$ & $(\%)$ & $\begin{array}{c}\text { Average } \\
\text { residual } \\
\text { deviation } \\
\quad(\mathrm{kg})\end{array}$ & $\begin{array}{l}S D \text { of } \\
\text { residual } \\
\text { deviation }\end{array}$ & $C V$ \\
\hline \multirow[t]{2}{*}{ Anglo-Nubian } & 1 & -0.1404 & 0.8217 & 17.09 & -0.1552 & 0.8222 & 18.88 \\
\hline & $\geq 2$ & 0.1063 & 0.9522 & 11.16 & 0.0742 & 0.9658 & 7.68 \\
\hline \multirow[t]{2}{*}{ Chamoisee } & 1 & -0.0624 & 0.7372 & 8.46 & -0.0751 & 0.7639 & 9.83 \\
\hline & $\geq 2$ & -0.2037 & 1.1779 & 17.29 & -0.2399 & 1.2092 & 19.84 \\
\hline \multirow[t]{2}{*}{ Saanen } & 1 & 0.1444 & 1.1934 & 12.10 & 0.1394 & 1.1962 & 11.65 \\
\hline & $\geq 2$ & 0.0426 & 1.4242 & 2.99 & 0.0525 & 1.4242 & 3.69 \\
\hline \multirow[t]{2}{*}{ Crossbreds } & 1 & 0.0990 & 0.9214 & 10.74 & 0.0957 & 0.9278 & 10.31 \\
\hline & $\geq 2$ & -0.1178 & 1.1607 & 10.15 & -0.1083 & 1.1623 & 9.32 \\
\hline
\end{tabular}

(IP or IG) was not clearly established. Lower coefficient of variation values were obtained for adult Saanen compared to other groups because it had the greatest number of observations $(39.7 \%$ of total observations compared to $19.8 \%$ for primiparous Saanen and $<10 \%$ for each other).

The curves for fat and protein yields decline from an initial peak yield (Bouloc, 1991; Stanton et al, 1992). In the equation

Table V. Means, standard deviations (SD), and coefficients of variation (CV) of residual deviations (observed - predicted) when cross-validating the incomplete gamma and inverse polynomial function parameters estimated from data set 1 on data set 2.

\begin{tabular}{|c|c|c|c|c|c|c|c|}
\hline \multirow[t]{2}{*}{ Breed } & \multirow[t]{2}{*}{ Parity } & \multicolumn{3}{|c|}{ Incomplete gamma } & \multicolumn{3}{|c|}{ Inverse polynomial } \\
\hline & & $\begin{array}{c}\text { Average } \\
\text { residual } \\
\text { deviation } \\
\quad(\mathrm{kg})\end{array}$ & $\begin{array}{l}S D \text { of } \\
\text { residual } \\
\text { deviation }\end{array}$ & (\%) & $\begin{array}{c}\text { Average } \\
\text { residual } \\
\text { deviation } \\
(\mathrm{kg})\end{array}$ & $\begin{array}{c}\text { SD of } \\
\text { residual } \\
\text { deviation }\end{array}$ & (\%) \\
\hline \multirow[t]{2}{*}{ Anglo-Nubian } & 1 & 0.1422 & 0.7816 & 18.19 & 0.1440 & 0.7856 & 18.30 \\
\hline & $\geq 2$ & -0.1079 & 0.8722 & 12.37 & -0.1099 & 0.8804 & 12.48 \\
\hline \multirow[t]{2}{*}{ Chamoisee } & 1 & 0.0693 & 0.8373 & 8.28 & 0.0650 & 0.8387 & 7.75 \\
\hline & $\geq 2$ & 0.2000 & 1.1722 & 17.06 & 0.1884 & 1.1880 & 15.86 \\
\hline \multirow[t]{2}{*}{ Saanen } & 1 & -0.1283 & 0.9753 & 13.15 & -0.1291 & 0.9770 & 13.21 \\
\hline & $\geq 2$ & 0.0062 & 1.3018 & 0.48 & 0.0180 & 1.3076 & 1.38 \\
\hline \multirow[t]{2}{*}{ Crossbreds } & 1 & -0.0990 & 0.8348 & 11.86 & -0.1084 & 0.8381 & 12.93 \\
\hline & $\geq 2$ & 0.1179 & 0.9924 & 11.88 & 0.1171 & 0.9925 & 11.80 \\
\hline
\end{tabular}


Table VI. Coefficients of multiple determination $\left(R^{2}\right)$ from fitting the inverse polynomial function to test day fat and protein yields.

\begin{tabular}{|c|c|c|c|}
\hline \multirow[t]{2}{*}{ Breed } & \multirow[t]{2}{*}{ Parity } & \multicolumn{2}{|c|}{$\mathrm{R}^{2}$} \\
\hline & & Fat & Protein \\
\hline \multirow[t]{2}{*}{ Anglo-Nubian } & 1 & 92.5 & 92.0 \\
\hline & $\geq 2$ & 89.6 & 90.6 \\
\hline \multirow[t]{2}{*}{ Chamoisee } & 1 & 89.4 & 89.6 \\
\hline & $\geq 2$ & 85.2 & 86.0 \\
\hline \multirow[t]{2}{*}{ Saanen } & 1 & 77.4 & 84.8 \\
\hline & $\geq 2$ & 76.8 & 84.2 \\
\hline \multirow[t]{2}{*}{ Crossbreds } & 1 & 85.2 & 88.3 \\
\hline & $\geq 2$ & 87.6 & 89.8 \\
\hline
\end{tabular}

for IG, this is accounted for by a negative $b$ (Bouloc, 1991); in that for IP, $a$ is the rate of increase to peak production and therefore is equal to zero for fat and protein, $b$ the average slope of the curve and $c$ the rate of decline after peak (Batra, 1986). The costs of running the NLIN procedures in the present study have been quite high. The cross-validation was not performed on fat and protein yields due to lack of funds. Table VI contains the $R^{2}$ resulting from fitting IP to TD fat and protein yields. The $R^{2}$ by breedparity group for fat or protein yields were comparable to those for milk, except the $R^{2}$ for fat were slightly lower than for others of the Saanen breed. Reasons for that decrease in $R^{2}$, though small, were not obvious from our data.

\section{Extrapolation factors}

In the present study, IP and IG were equally accurate in predicting TD milk yields. The integrals of these functions are required in order to estimate realized production. For the estimation of total milk production with IG, the gamma function is approximated, assuming the duration of lactation is infinite. That approximation is no longer possible for the estimation of cumulative yields at $25,50, \ldots, 225$ days, and for computing extension factors, these cumulative yields are needed. Because of that inconvenience, based on results obtained by other authors (Yadav et al, 1977; Mukundan and Bhat, 1983; Batra, 1986) and on the cross-validation in the present study, IP was preferred to IG to estimate extension factors.

Incomplete partial lactations are extended based on the partially realized production, last TD and days remaining to standard lactation length (Delgado and Martin, 1992). When last TD is not available (ie, for completed lactations < standard length), extrapolation is based only on partial yield (Barbat et al, 1995). The parameters for IP were used to derive extension factors at $25, \ldots, 225$ days. Extension factors only based on partial yields are shown in table VII; those based on both partial yield and last TD yield are demonstrated in table VIII.

\section{CONCLUSION}

Characteristics of lactation curves were estimated by the inverse polynomial and the incomplete gamma functions: initial yields all were constrained to zero, time of peak yield occurred later in lactation and peak yield was slightly higher with the inverse polynomial than with the incomplete gamma but time of peak yield estimates remained within the range found in the literature. Using nonlinear regression to estimate parameters of the models studied, evidence of the most suitable model for our data was not established based on the $R^{2}$ which tended to be slightly higher with the incomplete gamma than with the inverse polynomial. For practical reasons, the inverse polynomial was used to derive extension factors. 
Table VII. Extension factors $(k)$ for milk, fat and protein yields, based on partial yields $\left(Y_{p}\right)$ for the eight breed-parity classes.

\begin{tabular}{|c|c|c|c|c|c|c|c|c|}
\hline \multirow{2}{*}{$\begin{array}{l}\text { Breed: } \\
\text { Parity: }\end{array}$} & \multicolumn{2}{|c|}{ Anglo-Nubian } & \multicolumn{2}{|c|}{ Chamoisee } & \multicolumn{2}{|c|}{ Saanen } & \multicolumn{2}{|c|}{ Crossbreds } \\
\hline & 1 & $\geq 2$ & 1 & $\geq 2$ & 1 & $\geq 2$ & 1 & $\geq 2$ \\
\hline \multicolumn{9}{|l|}{ Milk } \\
\hline 25 days & 11.24 & 9.10 & 9.59 & 8.97 & 12.61 & 10.87 & 12.34 & 11.35 \\
\hline 50 days & 4.77 & 4.26 & 4.42 & 4.18 & 5.08 & 4.58 & 5.02 & 4.71 \\
\hline 75 days & 3.04 & 2.83 & 2.92 & 2.79 & 3.17 & 2.93 & 3.14 & 2.99 \\
\hline 100 days & 2.26 & 2.16 & 2.21 & 2.13 & 2.32 & 2.19 & 2.31 & 2.22 \\
\hline 125 days & 1.82 & 1.76 & 1.80 & 1.74 & 1.86 & 1.78 & 1.85 & 1.80 \\
\hline 150 days & 1.54 & 1.51 & 1.53 & 1.49 & 1.56 & 1.51 & 1.56 & 1.52 \\
\hline 175 days & 1.34 & 1.32 & 1.34 & 1.32 & 1.35 & 1.33 & 1.35 & 1.33 \\
\hline 200 days & 1.20 & 1.19 & 1.20 & 1.18 & 1.20 & 1.19 & 1.20 & 1.19 \\
\hline 225 days & 1.09 & 1.08 & 1.09 & 1.08 & 1.09 & 1.08 & 1.09 & 1.09 \\
\hline
\end{tabular}

Fat

$\begin{array}{lcccccccc}25 \text { days } & 10.31 & 10.41 & 9.16 & 8.32 & 9.66 & 8.05 & 9.94 & 8.56 \\ 50 \text { days } & 4.51 & 4.32 & 4.63 & 3.68 & 4.22 & 3.75 & 4.29 & 4.14 \\ 75 \text { days } & 2.92 & 2.78 & 3.12 & 2.46 & 2.76 & 2.54 & 2.79 & 2.79 \\ 100 \text { days } & 2.20 & 2.09 & 2.36 & 1.91 & 2.10 & 1.97 & 2.11 & 2.14 \\ 125 \text { days } & 1.78 & 1.71 & 1.91 & 1.60 & 1.72 & 1.64 & 1.72 & 1.76 \\ 150 \text { days } & 1.52 & 1.47 & 1.61 & 1.40 & 1.47 & 1.43 & 1.48 & 1.50 \\ 175 \text { days } & 1.33 & 1.30 & 1.39 & 1.26 & 1.30 & 1.27 & 1.30 & 1.32 \\ 200 \text { days } & 1.19 & 1.17 & 1.23 & 1.15 & 1.18 & 1.16 & 1.18 & 1.19 \\ 225 \text { days } & 1.09 & 1.08 & 1.10 & 1.07 & 1.08 & 1.07 & 1.08 & 1.08\end{array}$

Protein

\begin{tabular}{lcccccccc}
25 days & 12.04 & 10.93 & 10.81 & 11.22 & 11.74 & 10.39 & 8.05 & 11.54 \\
50 days & 4.94 & 4.55 & 4.56 & 4.44 & 4.92 & 4.47 & 4.14 & 4.78 \\
75 days & 3.11 & 2.91 & 2.92 & 2.80 & 3.12 & 2.89 & 2.83 & 3.03 \\
100 days & 2.30 & 2.18 & 2.19 & 2.10 & 2.31 & 2.17 & 2.18 & 2.25 \\
125 days & 1.84 & 1.76 & 1.77 & 1.71 & 1.85 & 1.77 & 1.79 & 1.81 \\
150 days & 1.55 & 1.50 & 1.51 & 1.46 & 1.56 & 1.50 & 1.53 & 1.53 \\
175 days & 1.35 & 1.32 & 1.32 & 1.29 & 1.35 & 1.32 & 1.34 & 1.34 \\
200 days & 1.20 & 1.19 & 1.19 & 1.17 & 1.21 & 1.19 & 1.20 & 1.20 \\
225 days & 1.09 & 1.08 & 1.08 & 1.08 & 1.09 & 1.08 & 1.09 & 1.09 \\
& & & & & & & & \\
\hline
\end{tabular}

Estimated yield: $Y_{e}=k Y_{p}$. 
Table VIII. Extension factors $(c)$ based on partial yield $\left(Y_{p}\right)$, days in milk $(t)$ and last test day milk yield $\left(y_{t}\right)$ for the eight breed-parity classes.

\begin{tabular}{|c|c|c|c|c|c|c|c|c|}
\hline \multirow{2}{*}{$\begin{array}{l}\text { Breed: } \\
\text { Parity: }\end{array}$} & \multicolumn{2}{|c|}{ Anglo-Nubian } & \multicolumn{2}{|c|}{ Chamoisee } & \multicolumn{2}{|c|}{ Saanen } & \multicolumn{2}{|c|}{ Crossbreds } \\
\hline & 1 & $\geq 2$ & 1 & $\geq 2$ & 1 & $\geq 2$ & 1 & $\geq 2$ \\
\hline \multicolumn{9}{|l|}{ Milk } \\
\hline 25 days & 0.862 & 0.780 & 0.811 & 0.760 & 0.919 & 0.819 & 0.907 & 0.843 \\
\hline 50 days & 0.816 & 0.785 & 0.807 & 0.766 & 0.836 & 0.776 & 0.832 & 0.789 \\
\hline 75 days & 0.825 & 0.810 & 0.827 & 0.794 & 0.835 & 0.791 & 0.833 & 0.800 \\
\hline 100 days & 0.847 & 0.838 & 0.851 & 0.824 & 0.851 & 0.818 & 0.850 & 0.825 \\
\hline 125 days & 0.871 & 0.866 & 0.877 & 0.856 & 0.874 & 0.849 & 0.873 & 0.853 \\
\hline 150 days & 0.898 & 0.895 & 0.903 & 0.886 & 0.899 & 0.880 & 0.898 & 0.883 \\
\hline 175 days & 0.924 & 0.922 & 0.928 & 0.916 & 0.924 & 0.911 & 0.924 & 0.913 \\
\hline 200 days & 0.950 & 0.949 & 0.953 & 0.945 & 0.950 & 0.942 & 0.950 & 0.943 \\
\hline 225 days & 0.975 & 0.975 & 0.977 & 0.973 & 0.975 & 0.971 & 0.975 & 0.972 \\
\hline
\end{tabular}

Fat

$\begin{array}{lllllllll}25 \text { days } & 0.813 & 0.759 & 0.916 & 0.627 & 0.748 & 0.658 & 0.759 & 0.769 \\ 50 \text { days } & 0.788 & 0.719 & 0.926 & 0.634 & 0.732 & 0.677 & 0.735 & 0.785 \\ 75 \text { days } & 0.805 & 0.742 & 0.936 & 0.680 & 0.759 & 0.720 & 0.760 & 0.813 \\ 100 \text { days } & 0.832 & 0.778 & 0.945 & 0.731 & 0.794 & 0.764 & 0.794 & 0.841 \\ 125 \text { days } & 0.860 & 0.817 & 0.955 & 0.782 & 0.830 & 0.808 & 0.830 & 0.869 \\ 150 \text { days } & 0.889 & 0.856 & 0.964 & 0.830 & 0.866 & 0.850 & 0.866 & 0.897 \\ 175 \text { days } & 0.918 & 0.894 & 0.973 & 0.876 & 0.902 & 0.890 & 0.901 & 0.924 \\ 200 \text { days } & 0.946 & 0.931 & 0.982 & 0.919 & 0.936 & 0.929 & 0.935 & 0.950 \\ 225 \text { days } & 0.973 & 0.966 & 0.991 & 0.961 & 0.968 & 0.965 & 0.968 & 0.975\end{array}$

Protein

$\begin{array}{lllllllll}25 \text { days } & 0.892 & 0.810 & 0.815 & 0.777 & 0.892 & 0.799 & 0.806 & 0.858 \\ 50 \text { days } & 0.825 & 0.763 & 0.774 & 0.710 & 0.836 & 0.769 & 0.830 & 0.801 \\ 75 \text { days } & 0.828 & 0.779 & 0.790 & 0.729 & 0.840 & 0.788 & 0.854 & 0.809 \\ 100 \text { days } & 0.847 & 0.808 & 0.817 & 0.765 & 0.858 & 0.816 & 0.877 & 0.832 \\ 125 \text { days } & 0.871 & 0.840 & 0.848 & 0.806 & 0.880 & 0.848 & 0.899 & 0.859 \\ 150 \text { days } & 0.896 & 0.874 & 0.879 & 0.847 & 0.904 & 0.880 & 0.920 & 0.888 \\ 175 \text { days } & 0.923 & 0.906 & 0.911 & 0.887 & 0.928 & 0.911 & 0.941 & 0.917 \\ 200 \text { days } & 0.949 & 0.939 & 0.941 & 0.926 & 0.953 & 0.941 & 0.961 & 0.945 \\ 225 \text { days } & 0.975 & 0.970 & 0.971 & 0.964 & 0.977 & 0.971 & 0.981 & 0.973\end{array}$

Estimated yield: $Y_{e}=Y_{p}+c \cdot(250-t) \cdot y_{t}$. 


\section{ACKNOWLEDGMENTS}

The authors are very grateful to the Fédération nationale des éleveurs de chèvres et moutons laitiers of which test day data were provided by the OPPEw and to the Ministère de la Région wallonne, Direction générale de l'agriculture.

\section{REFERENCES}

Anderson SM, Mao IL, Gill JL (1989) Effect of frequency and spacing of sampling on accuracy and precision of estimating total lactation milk yield and characteristics of the lactation curve. J Dairy Sci 72, 23872394

Auran T (1976) Studies on monthly and cumulative monthly milk yield records. IV. Estimating total lactation from part-lactation. Acta Agric Scand 26, 10-17

Barbat A, Bonaiti B, Boichard D (1995) Comparaison de 2 méthodes de précorrection des lactations courtes pour l'évaluation des reproducteurs laitiers. Ann Zootech 44, 161-172

Batra TR (1986) Comparison of two mathematical models in fitting lactation curves for pureline and crossline dairy cows. Can J Anim Sci 66, 405-414

Boichard D, Manfredi E, Piacere A, Sigwald JP, Bonaiti B (1993) Après IF2 : une nouvelle méthode pour évaluer la génétique des caprins laitiers. Chèvre 192, 16-19

Bouloc N (1991) Analyse de la forme de la courbe de lactation. Application à l'étude des modalités d'allègement du contrôle laitier et de prévision précoce de la production dans l'espèce caprine. Thèse de doctorat, INA, Paris-Grignon, France

Christensen LG (1970) Progeny testing of dairy sires based on field and test-station data. I. Phenotypic and genetic relations. Acta Agric Scand 20, 293-301

Delgado FJ, Martin TG (1992) Extension factors for incomplete lactations of Sierra-da-Estrela sheep. $J$ Dairy Sci 75, 1731-1735

Gipson TA, Grossman M (1987) Lactation curves in dairy goats. In: Proc IV Int Conf on Goats, Embrapa Brasilia, Brazil, 1448-1449

Gipson TA, Grossman M (1990) Lactation curves in dairy goats: a review. Small Rumin Res 3, 383-396

Grossman M, Koops WJ (1988) Multiphasic analysis of lactation curves in dairy cattle. J Dairy Sci 71, 15981608

Keown JF, Van Vleck LD (1973) Extending lactation records in progress to 305 -day equivalent. J Dairy Sci $56,1070-1079$

Kuck AL, Grossman M, Norton HW (1976) Studies of the lactation curve of purebred and crossbred dairy cattle. In: 71st Annu Meeting Am Dairy Sci Assoc, 131 (abstr)
Masselin S, Sauvant D, Chapoutot P, Milan D (1987) Les modèles d'ajustement des courbes de lactation. Ann Zootech 36, 171-206

Miller RH, Hooven NW Jr, Smith JW, Harvey WR, Creegan ME (1972a) Modified regression for estimating total lactation from part-lactation yields. J Dairy Sci $55,208-213$

Miller RH, Pearson RE, Fohrman MH, Creegan ME (1972b) Methods of projecting complete lactation production from part-lactation yield. J Dairy Sci 55 , 1602-1606

Mukundan G, Bhat PN (1983) Lactation curve in Malabari goats and their Saanen half-breds. Ind $J A$ nim Sci 53, 666-669

Nelder JA (1966) Inverse polynomials, a useful group of multi-factor response functions. Biometrics 22, 128-141

Ptak E, Schaeffer LR (1993) Use of test day yields for genetic evaluation of dairy sires and cows. Livest Prod Sci 34, 23-34

Pander BL, Hill WG (1993) Genetic evaluation of lactation yield from test day records on incomplete lactation. Livest Prod Sci 37, 23-36

Ricordeau G, Bouillon J (1967) Estimation des performances laitières des chèvres à partir des lactations partielles : quantité de lait, richesse en matière grasse et protéines. Bull Tech Ing Serv Agric 218, 303-310

SAS (1985) User's Guide: Statistics, Version 5 Edition. SAS Institute Inc, Cary, NC, USA

Schaeffer LR, Sullivan BP (1994) Genetic evaluation of dairy goats using test day yields. In: Proc 5 th World Congr Genet Appl Livestock Production, 7-12 August 1994, Guelph, ON, Canada, 18, 182-185

Schaeffer LR, Minder CE, McMillan I, Burnside EB (1977) Nonlinear techniques for predicting 305-day lactation production of Holsteins and Jerseys. J Dairy Sci $60,1636-1644$

Stanton TL, Jones LR, Everett RW, Kachman SD (1992) Estimating milk, fat and protein lactation curves with a test day model. J Dairy Sci 75, 1691-1700

Van Vleck LD, Henderson CR (1961) Utilizing both part and complete daughter records in sire evaluation. $J$ Dairy Sci 44, 2068-2076

Wiggans GR, Van Vleck LD (1979) Extending partial lactation milk and fat records with a function of last sample production. J Dairy Sci 62, 316-325

Wiggans GR, Van Vleck LD, Dickinson FN (1979) Projection factors for goat lactation records. J Dairy Sci 62, 797-801

Wilmink JBM (1987) Comparison of different methods of predicting 305-day milk yield using means calculated from within-herd lactation curves. Livest Prod Sci $17,1-17$

Wood PDP (1967) Algebraic model of the lactation curve in cattle. Nature 216, 164-165

Yadav MC, Katpatal BG, Kaushik SN (1977) Study of lactation curve in Hariana and its Friesian crosses. Ind J Anim Sci 47, 607-609 